\title{
Preparation and Characterization of $\left[\mathrm{C}_{6} \mathrm{H}_{5} \mathrm{CH}_{2} \mathrm{NH}_{3}\right]_{2} \mathrm{PbI}_{4}$,
}

$\left[\mathrm{C}_{6} \mathrm{H}_{5} \mathrm{CH}_{2} \mathrm{CH}_{2} \mathrm{SC}\left(\mathrm{NH}_{2}\right)_{2}\right]_{3} \mathrm{PbI}_{5}$ and $\left[\mathrm{C}_{10} \mathrm{H}_{7} \mathrm{CH}_{2} \mathrm{NH}_{3}\right] \mathrm{PbI}_{3}$ Organic-Inorganic Hybrid Compounds

G. C. Papavassiliou ${ }^{\mathrm{a}}$, G. A. Mousdis ${ }^{\mathrm{a}}$, C. P. Raptopoulou ${ }^{\mathrm{b}}$, and A. Terzis ${ }^{\mathrm{b}}$

a Theoretical and Physical Chemistry Institute, National Hellenic Research Foundation, 48, Vassileos Constantinou Ave., Athens 116/35, Greece

${ }^{b}$ Institute of Materials Science, NCSR, Demokritos, Athens 153/10, Greece

Reprint requests to Prof. G. C. Papavassiliou. Fax: (301) 7273794

Z. Naturforsch. 54 b, 1405-1409 (1999); received July 7, 1999

Organic-Inorganic Hybrides, Perovskites, Low-Dimensional Compounds, Excitonic Spectra

The preparation, crystal structures, optical absorption spectra, and photoluminescence spectra of the title compounds are reported. The compounds were prepared in single crystal form. $\left[\mathrm{C}_{6} \mathrm{H}_{5} \mathrm{CH}_{2} \mathrm{NH}_{3}\right]_{2} \mathrm{PbI}_{4}$ consists of anionic perovskite sheets of corner-sharing $\mathrm{PbI}_{6}$ octahedra, which alternate with the $\mathrm{C}_{6} \mathrm{H}_{5} \mathrm{CH}_{2} \mathrm{NH}_{3}{ }^{+}$sheets. $\left[\mathrm{C}_{6} \mathrm{H}_{5} \mathrm{CH}_{2} \mathrm{CH}_{2} \mathrm{SC}\left(\mathrm{NH}_{2}\right)_{2}\right]_{3} \mathrm{PbI}_{5}$ consists of zig-zag chains of anionic corner sharing $\mathrm{PbI}_{6}$ octahedra separated by $\mathrm{C}_{6} \mathrm{H}_{5} \mathrm{CH}_{2} \mathrm{CH}_{2} \mathrm{SC}\left(\mathrm{NH}_{2}\right)_{2}$ cations. $\left[\mathrm{C}_{10} \mathrm{H}_{7} \mathrm{CH}_{2} \mathrm{NH}_{3}\right] \mathrm{PbI}_{3}$ consists of twin chains of edge-sharing $\mathrm{PbI}_{6}$ octahedra separated by $\mathrm{C}_{10} \mathrm{H}_{7} \mathrm{CH}_{2} \mathrm{NH}_{3}$ cations. The compounds are thus low-dimensional systems. The excitonic spectra were observed in all cases, even at room temperature, and the possibility of organicinorganic excitonic interactions is discussed. 